\title{
Cytochrome P450 aromatase (CYP19) gene expression in ovarian granulose cells of hypothyroid rats induced by propylthiouracil
}

\author{
Prihatin Broto Sukandar ${ }^{1}$, Sri Kadarsih Soejono ${ }^{2}$, Totok Utoro ${ }^{3}$ \\ ${ }^{1}$ Center for Research and Development for lodine Deficiency Disorders, Magelang, Central \\ Java, ${ }^{2}$ Department of Physiology, ${ }^{3}$ Department of Pathology Anatomy, Faculty of \\ Medicine, Universitas Gadjah Mada, Yogyakarta
}

\begin{abstract}
Thyroid hormones are proven to have a direct effect on granulose cells, luteal cells and oocytes due to their role in gonadotropin action on steroid hormone production. In vitro study showed that tiroxine (T4) on granulose cells can stimulate ovarian steroidogenesis. Moreover, high concentration of triiodothyronine (T3) increases the estradiol secretion and aromatase mRNA expression. Hypothyroidism influences the cytochrome P450 aromatase (CYP19) gene expression. The aim of this study was to evaluate the expression of the CYP19 gene in granulosa cells of hypothyroid rats induced by propylthiouracil (PTU). This was quasi experimental study with post-test only control group design. Eleven female Sprague-Dawley rats were divided into two groups i.e. five rats as treated group that induced by PTU $0.1 \mathrm{~g} / \mathrm{L}$ in aquadest for 30 days and control group that not induced by PTU. Blood sample was taken and then T4 blood level was measured using an enzyme-linked immunosorbent assay (ELISA). Whereas, CYP19 gene expression in ovarian granulose cells was measured using immunohistochemistry. Unpaired t test was used to compare the data obtained from treated and control groups. The results showed that T4 blood level on treated group (4.02 $\pm 0.39 \mathrm{ng} / \mathrm{dL})$ was significantly lower than control group $(8.08 \pm 1.63 \mathrm{ng} / \mathrm{dL})(\mathrm{p}=0.000)$. However, CYP19 gene expression on treated group (30.84 \pm $8.01 \%)$ was not significantly different compare to control group (25.06 $\pm 6.79 \%)(p=0.227)$. In conclusion, the CYP19 gene expression in ovarian granulose cells of rats is not change after induction of PTU $0.1 \mathrm{~g} / \mathrm{L}$ for 30 days, although the T4 blood level decreases.
\end{abstract}

\section{ABSTRAK}

Hormon tiroid terbukti mempunyai efek langsung pada sel granulosa, sel luteal dan oosit karena perannya aksi gonadotropin dalam memproduksi hormon steroid. Kajian in vitro membuktikan bahwa tiroksin (T4) mampu menstimulasi sterreogenesis ovarium. Kadar triiodotironin (T3) yang tinggi akan meningkatkan sekresi estradiol dan ekspresi sitokrom P450 19 (CYP19) mRNA. Hipotiroidisme dapat mempengaruhi ekspresi gen CYP19 aromatase. Penelitian ini bertujuan untuk mengkaji ekspresi gen CYP19 sel granulosa tikus hipotiroid yang diinduksi oleh propiltiourasil (PTU). Penelitian ini merupakan penelitian eksperimental kuasi dengan rancangan post-test only control group. Sebelas tikus Sprague-Dawley betina dibagi menjadi dua kelompok yaitu lima tikus sebagai kelompok perlakuan yang diinduksi oleh 0,1 g/L PTU dalam akuades selama 30 hari dan kelompok kontrol yang tidak diinduksi PTU. Sampel darah diambil dan ditetapkan kadar T4 darah dengan enzyme-linked immunosorbent assay (ELISA). Sedangkan ekspresi gen CYP19 diukur dengan metode imunohistokimia. Uji t tidak berpasangan digunakan untuk membandingkan data yang diperoleh dari kelompok perlakuan dan kelompok kontrol. Hasil penelitian menunjukkan kadar T4 darah pada kelompok perlakuan $(4,02 \pm 0,39 \mathrm{ng} / \mathrm{dL})$ lebih rendah secara nyata

\footnotetext{
* corresponding author: prihatin.sukandar@gmail.com
} 
dibandingkan dengan kelompok kontrol $(8.08 \pm 1,63 \mathrm{ng} / \mathrm{dL})(\mathrm{p}=0,000)$. Namun demikian, ekspresi gene CYP19 pada kelompok perlakuan $(30,84 \pm 8,01 \%)$ tidak berbeda nyata dibandingkan kelompok kontrol $(25,06 \pm 6,79 \%)(p=0,227)$. Dapat disimpulkan, ekspresi gene CYP19 pada sel granulosa ovari tikus tidak berubah setelah induksi $0,1 \mathrm{~g} / \mathrm{L}$ PTU selama 30 hari, meskipun kadar T4 darah mengalami penurunan.

Key words : CYP19 - aromatase - T4 blood level - propylthiouracil - hypothyroid

\section{INTRODUCTION}

Iodine deficiency disorder (IDD) is one of the nutrition problems in Indonesia. ${ }^{1}$ It is highly associated with infertility, stillbirths, lactation failure, and abnormalities menstruation. ${ }^{2}$ An estimated 750 million people in the world are at risk of suffering from IDD. ${ }^{3}$ In Indonesia, based on a survey of thyroid in children, the national Total Goitre Rate (TGR) was 9.8\% in 1998 and $11.1 \%$ in $2003 .{ }^{4}$ The rates are still above the WHO recommendation, which is less than $5 \%$. The prevalence of hypothyroidism in the general population of reproductive age is about 2\%. ${ }^{5}$ Previous study by Auchus and Chang ${ }^{6}$ showed that thyroid disease occurs five to ten times more in women than men, and the highest incidence occurs at reproductive age. Marijata's ${ }^{7}$ study at a hospital in Wonosari, Yogyakarta, Indonesia found that $90 \%$ of goitre patients are female and $10 \%$ are male .

Hypothyroidism affects the granulose cells, luteal cells, oocytes and eventually leads to ovarian dysfunction. ${ }^{8}$ Mild hypothyroidism interfere ovulation and conception. ${ }^{9}$ Severe hypothyroidism often leads to ovulatory dysfunction and infertility. ${ }^{10}$ There is a causal relationship between hypothyroidism and the development of various ovarian disorders (enlarged polycystic ovaries, cysts, and spontaneous hyperstimulation ovarian syndrome). ${ }^{11}$

Reduction of thyroid function may alter pituitary-ovarian axis. In hypothyroid condition, the pituitary is more sensitive to produce thyroid stimulating hormone (TSH) or thyroid realising hormone (TRH). Thyrotropin releases hormone that stimulates lactotrop cells to synthesize prolactin. Prolactin interfere GnRH pulsatility and suppresses follicle stimulating hormone (FSH) and luteinizing hormone (LH), and as a consequences there is no follicle maturation. Furthermore, prolactin stimulates adrenal androgen secretion, lead to the increasing of androgen serum and follicle maturation stunts..$^{6,12}$ Treatment of hypothyroidism with L-thyroxine (L-T4) can restore normal menstrual pattern and ovarian disorders. ${ }^{10}$

In addition, the effects of hypothyroidism can impair hypothalamic-pituitary axis and the function of ovaries. Hypothyroidism can reduce sex hormone binding globulin (SHBG) affinity and that increase free testosterone and estradiol due to lower clearance rate of androstenedione and estron. ${ }^{6}$ Ovarian enlargement in severe hypothyroidism is probably due to stimulation of FSH receptor by unusually high TSH levels. TSH has a weak FSH-like activity. ${ }^{13}$ Thyroid hormones play a role in modulating $\mathrm{LH}$ and $\mathrm{FSH}$ on granulose cells function to induce steroidogenesis. ${ }^{14}$

Several studies found that one of the genes that influence the process of steroidogenesis is cytochrome P450 19(CYP19) gene. The CYP19 gene is located in chromosome 15 on the long arm (15q21.1). It encodes the CYP aromatase enzyme and catalyzes the final step of the biosynthesis of estrogen from testosterone to estradiol and androstenedione to estron. ${ }^{15}$ Estrogen production depends on aromatase activity granulose cells in the inner layer of 
ovarian follicle. Estrogen precursors such as testosterone are supplied by cells in the outer layer of the follicle (theca cells). Aromatase is a reliable marker for ovarian granulose cells in mammalian. ${ }^{16,17}$ Several cases with estrogen deficiency reduce aromatase activity. Conversely, the increase aromatase activity can lead to gynecomastia and feminization in males. ${ }^{18}$ Experiments with T4 administration on granulose cells culture proved to stimulate ovarian steroidogenesis. ${ }^{6}$

Propylthiouracil (PTU) treated rats have been used as an animal model to study hypothyroid ovarian follicular cysts and steroidogenesis. This model can be used to investigate the biochemical changes intraovarium. ${ }^{19}$ Hypothyroidism affects the expression of CYP19 gene encoding aromatase. This study was conducted to evaluate the expression of CYP19 gene in ovarian granulose cells of hypothyroid rats induced by PTU.

\section{MATERIALS AND METHODS}

\section{Animals and hypothyroid induction}

This was a experimental study with posttest only control group design. Twelve SpragueDawley female rats aged 10 weeks with average of body weight of $111.08 \pm 8.10 \mathrm{~g}$ obtained from the Integrated Research and Testing Laboratory (Laboratorium Penelitian dan Pengujian Terpadu = LPPT), Universitas Gadjah Mada, Yogyakarta were used in this study. The rats were housed in the Laboratory of Physiology, Faculty of Medicine, Universitas Gadjah Mada at room temperature under 12 hours cycles of dark and light. The rats were fed with AD-II pellet (PT. Japfa Comfeed Indonesia, Tbk, Sidoarjo) and provided an access to water ad libitum. After an adaptation period of one week, the rats were divided into two groups with six rats in each group. The animal sample size was calculated according to the software of Ramakrishnan, ${ }^{20}$ or formula of $\mathrm{n}=1+2 \mathrm{C}(\mathrm{s} / \mathrm{d})^{2}$ described by Dell et $a l .{ }^{21}$ The first group as control was without PTU induction. The second group as treatment group was induced by PTU $0.1 \mathrm{~g} / \mathrm{L}$ in aquadest for 30 days according to the protocol described by Hapon et al. ${ }^{22}$

\section{Thyroxine blood level assay}

On day 30 after PTU induction, blood samples were collected from orbital sinus and T4 blood leve was measured. Two $\mathrm{mL}$ blood sample was centrifuged at $3000 \mathrm{rpm}$ (rounds per minuts) for 10 minutes. Serum sample was taken and kept at 2-8 ${ }^{\circ} \mathrm{C}$ for 24 hours until T4 serum level analyzed. The T4 serum level was then measured using ELISA. Fifty $\mu$ L of serum sample was pippeted into each well of a microtiter well coated antibody to T4 on a solid phase. One hundred $\mu \mathrm{L}$ of T4 labeled with sheep peroxidase conjugate were added into each well and incubated at room temperature. After a 60 minute incubation, the microtiter well was washed with a washing solution containing surfactant in Tris beffered saline. A solution of tetramethylbenzidine (TMB) was added and incubated for 15 minutes resulting in the development of a blue color. The color development was stopped with the addition 100 $\mu \mathrm{L}$ stopping solution containing $0.25 \mathrm{M}$ sulphuric acid. The resulting yellow color was measured ELISA reader at $450 \mathrm{~nm}$. The intensity of the color formed was proportional to the amount of enzyme present and was inversely related to the amount of T4 in the serum sample. By reference to a series of standard processed in the same way, the concentration of T4 in the unknown serum sample was calculated.

\section{CYP19 gen expression assay}

After blood samples taken, rats were sacrificed. The rats were anesthetized using ketamine $\mathrm{HCl}$. A transverse abdominal incision was made and ovarian tissue was removed from 
the rat. The right ovarian tissue was then made histological preparations. The formalin-fixed and paraffin-embedded tissues were cut into serial tissue sections at a thickness of $3 \mu \mathrm{m}$. Each slide contains 4 tissue sections e.g. two sections as control and two sections as treatment group. Following deparaffinization, the sections were blocked with normal rabbit serum for 5 minutes. The sections were then incubated with polyclonal antibody anti CYP19 solution (1:50) purchased from Santa Cruz Biotechnology, Inc. for 60 minutes. The sections were washed with $10 \%$ phosphate buffered saline (PBS) three time for 5 minutes and incubated with diaminobenzidine (DAB) for 5 minutes. The sections were then lightly countersatined by haemato-

$$
\% \text { of CYP19 expression positive cells }=\frac{\text { Total cells CYP19 positive }}{\text { Total cells }} \times 100 \%
$$

\section{Statistical analysis}

Data were presented in the form of mean \pm standard error of mean (SEM). Statistical analysis was performed by unpaired $t$ test with significance level of $p<0.05$. If the data distribution was not normal, the Mann-Whitney test was used. This study was approved by the the Medical and Health Research Ethic Committee, Faculty of Medicine, Universitas Gadjah Mada, Yogyakarta.

\section{RESULTS}

xylin mayer and incubated for 3 minutes at room temperature and washed in water for 10-15 minutes. The sections were then dried and coverslipped. All sections were then examined and evaluated using light microscope on 400x magnifications. The observation of CYP19 expression was performed in the Department of Pathology Anatomy at Faculty of Medicine/ Dr. Sardjito General Hospital, Universitas Gadjah Mada. The CYP19 expression in ovarian granulose cells was identified by a brown color in cytoplasma of the cell, while a blue color of a ovarian granulose cell indicated no expression of the CYP19. The CYP19 expression was observed on each sections and percentage of the CYP19 expression was calculated using a formula as follows:

Among six rats induced by PTU in treatment group, one rats did not showed hypothyroid. Therefore only five hypothyroid rats in the treatment group were used in this study. The body weight $(\mathrm{BW})$ of rats in both control $(108.17 \pm 10.76 \mathrm{~g})$ and treatment groups (114.00 $\pm 5.44 \mathrm{~g}$ ) before induced with PTU were not significantly different $(p>0.05)$. At the end of the study, the BW of all rats in both increased. The average $\mathrm{BW}$ gain of the control group rats $(55.5 \mathrm{~g})$ was higher than the treatment group $(11.0 \mathrm{~g})(\mathrm{p}<0.05)(\mathrm{TABLE} 1)$.

TABLE 1. The BW (mean \pm SEM) of rats in both groups before and after induced with PTU $0.1 \mathrm{~g} /$ $\mathrm{L}$ in aquadest for 30 days

\begin{tabular}{llcccc}
\hline Group & $\begin{array}{c}\text { Pre-induced BW } \\
(\mathrm{g})\end{array}$ & $\mathrm{p}$ & $\begin{array}{c}\text { Post-induced BW } \\
(\mathrm{g})\end{array}$ & $\mathrm{p}$ & $\Delta \mathrm{BW}$ \\
\hline Control $(\mathrm{n}=6)$ & $114.00 \pm 5.44$ & \multirow{2}{*}{0.299} & $\begin{array}{l}169.50 \pm 13.82 \\
119.17 \pm 12.12\end{array}$ & \multirow{2}{*}{0.000} & +55.5 \\
Treatment $(\mathrm{n}=5)$ & $108.17 \pm 10.76$ & & +11.0 \\
\hline
\end{tabular}

The T4 blood sample after induction of PTU $0.1 \mathrm{~g} / \mathrm{L}$ for 30 days in the treatment group $(4.02$ $\pm 0.39 \mathrm{ng} / \mathrm{dL})$ was significantly lower than control group $(8.08 \pm 1.63 \mathrm{ng} / \mathrm{dL})(\mathrm{p}<0.05)$ 
(TABLE 2). It was indicated that the PTU induction caused hypothyroid of the rats.

TABLE 2. The T4 blood level (mean \pm SEM) of rats in both groups before and after induced with PTU $0.1 \mathrm{~g} / \mathrm{L}$ in aquadest for 30 days

\begin{tabular}{lcc}
\hline Group & $\begin{array}{c}\text { T4 blood level } \\
(\mathrm{ng} / \mathrm{dL})\end{array}$ & $\mathrm{p}$ \\
\hline Control $(\mathrm{n}=6)$ & $8.08 \pm 1.63$ & 0.000 \\
Treatment $(\mathrm{n}=5)$ & $4.02 \pm 0.39$ & \\
\hline
\end{tabular}

The CYP19 expression in ovarian granulose cells of rats in both control and treatment groups is presented in FIGURE 1, while the level CYP19 expression in the both groups is presented in TABLE 3. The average CYP19 expression in the treatment group $(30.84$ $\pm 8.01 \%$ ) was not significantly different compare the control group $(25.06 \pm 6.79 \%)$.

Table 3. Aromatase CYP19 gene expression on rats ovaries control and treated group after administration of PTU $0.1 \mathrm{~g} / \mathrm{L}$ in drinking water for 30 days (mean \pm SEM).

\begin{tabular}{lcc}
\hline Group & aromatase CYP19 gene expression & $\mathrm{p}$ \\
& $(\%)$ & \\
\hline Control $(\mathbf{n}=6)$ & $25.06 \pm 6.79$ & 0.227 \\
Treatment $(\mathbf{n}=5)$ & $30.84 \pm 8.01$ & \\
\hline
\end{tabular}
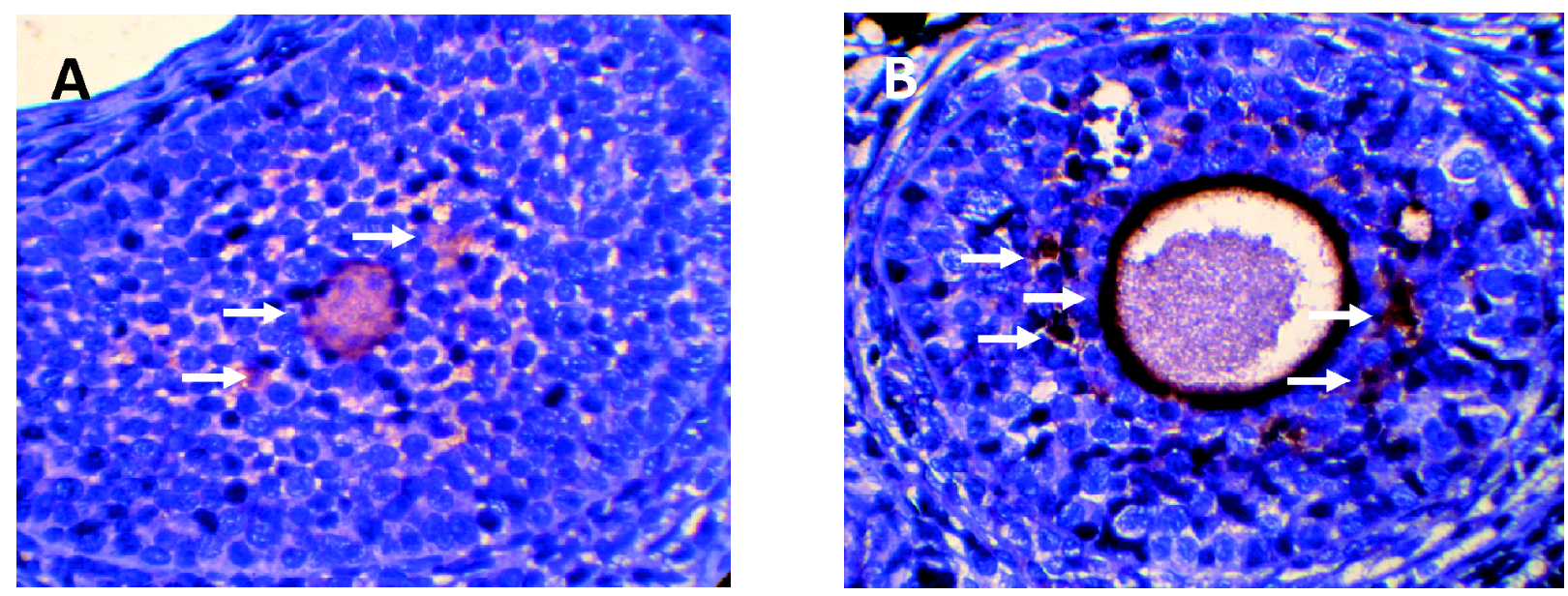

FIGURE 1. CYP19 expression in ovarian granulose cells. The arrows indicated CYP expression positive cells. A. control group and B. treatment group. Light microscope observation on $400 \mathrm{x}$ magnification.

\section{DISCUSSION}

The free T4 blood levels in treatment group were statistically lower than control group $(\mathrm{p}<0.05)$. This suggests that ingestion of PTU $0.1 \mathrm{~g} / \mathrm{L}$ for 30 days was able to induce hypothyroidism. ${ }^{22}$
Weight gain was significantly higher in the control group compared to treatment group $(p<0.05)$. It was consistent with research by Cooke et al. ${ }^{23}$ which showed that hypothyroidism had a slow trend in weight gain compared to euthyroid. In thyroidectomy rats, hypothyroi- 
dism inhibits weight gain. ${ }^{24}$ Thyroid hormones affects tissue growth, brain maturation, increases heat production and oxygen consumption due to increased activity of $\mathrm{Na}^{+}-\mathrm{K}^{+}$-ATPase, as well as increased transport of glucose and amino acids. ${ }^{25}$ Thyroid hormone also stimulates the secretion of growth hormone and stimulates the growth hormone effects (somatomedin) on protein and new structural bones synthesis. ${ }^{26}$

The results of this study showed that the expressions of CYP19 gene in granulose cells between the control group and the treatment group were similar. According to the research by Hapon et al..$^{22} \mathrm{PTU}$-induced hypothyroidism with dose $0.1 \mathrm{~g} / \mathrm{L}$ given for 30 days did not reduce estradiol serum levels. However, the prolongation of PTU administration until 50 days decreases the estradiol serum levels.

In hypothyroid, free T3 may be normal. This is caused by the influence of thyroid tissue remnants that are still have normal function under the influence of increased TSH. T4 is converted to T3, and cause lower T4 level. As a consequence of this mechanism, free T3 levels remain within normal limits. ${ }^{27}$ The active form of thyroid hormone (T3) regulates development and physiological functions at the cellular level, control metabolism, proliferation, differentiation, and apoptosis. T3 mostly affects transcription gene by binding to the thyroid hormone receptor found in nucleus. ${ }^{28}$ However, no other studies correspond with the results of this study. CYP19 gene expression will be decreased when levels of thyroid hormone (T3) is low, thus affecting gene transcription. ${ }^{28}$ Free T3 levels in this study were not measured. Research by Hatsuta et al. ${ }^{29}$ proved that the addition of T3 with normal dosage did not affect the secretion of estradiol. However, low dosage of estradiol reduce the secretion of estradiol, presumably through the reduction of CYP19 mRNA expression in granulose cells. Another study by Hapon et al ${ }^{30}$ stated that the administration of PTU $0.1 \mathrm{~g} / \mathrm{L}$ for 8 days in virgin rats can increase CYP19, whereas T4 serum levels stay normal.

In hypothyroidism condition, gonadotropin (FSH and $\mathrm{LH}$ ) production is not interfere by the pituitary, ${ }^{31}$ while it is known that FSH is a major trigger of aromatase activity. ${ }^{32}$ Hypothyroidism can inhibit the growth and development of the follicles, but the follicles are still able to produce steroid hormones. It happens because during this condition, only the number and size of corpura lutea cells are reduced..$^{31}$ Corpora lutea is the major source of the hormone progesterone. Reduction of the size and the cell numbers of will reduce the production of progesteron, but it will induce the development of estrogen receptors in granulose cells. Estrogen hormone stimulation normal granulose cells development and it leads to normal process of aromatization. ${ }^{33}$ Furthermore, ovarian enlargement in severe hypothyroidism is probably due to the stimulation of FSH receptor induced by high TSH levels. TSH has a weak FSH-like activity because it similar to the subunit $\alpha$ of FSH and LH. ${ }^{13}$ Recent study showed that estrogen production that induced by aromatization is not interfered by ovarian enlargement.

\section{CONCLUSION}

It can be concluded that the administration of PTU $0.1 \mathrm{~g} / \mathrm{L}$ for 30 days does not influence the CYP19 gene expression in ovarian granulose cells of rats, although it can decrease the T4 blood levels. Further studies will be conducted to evaluate the effect of PTU induction in longer period. Moreover, other indicators of reproductive hormones level such as T3 will be studied.

\section{ACKNOWLEDGEMENTS}

The authors would like to thank Ms. Agustin from the Laboratory of Pathology Anatomy, 
Universitas Gadjah Mada/Dr. Sardjito General Hospital for her valuable assistance in immunohistochemistry staining techniques and $\mathrm{Mr}$. Wakidi Parno from Laboratory of Physiology, Faculty of Medicine, Universitas Gadjah Mada for his assistance in animal handling and treatment.

\section{REFERENCES}

1. Astawan M. Iodium cegah lost generation. [cited 2011 April 11]. Available from: www.gizi.net/cgibin/berita/fullnews.cgi?newsid 1043213364 , 24317

2. Thomas R, Reid RL. Thyroid disease and reproductive dysfunction: a review. Obstet Gynecol. 1987; 70(5):789-98.

3. Anonim. Assessment of the iodine deficiency disorders and monitoring their elimination. Geneva: World Health Organization, 2001.

4. Anonim. Technical assistanc for evaluation on intensified iodine deficiency control project. Jakarta: Directorate General of Community Health, Directorate of Community Nutrition, 2003

5. Bjoro T, Holmen J, Kruger O, Midthjell K, Hunstad $\mathrm{K}$, Schreiner $\mathrm{T}$, et al. Prevalence of thyroid disease, thyroid dysfunction and thyroid peroxidase antibodies in a large, unselected population. The Health Study of Nord-Trondelag (HUNT). Eur J Endocrinol 2000; 143(5):639-47.

6. Chang AY, Auchus RJ, Endocrine disturbances affecting reproduction. In: Yen, SSC, RB Jafee RB, editors. Reproductive endocrinology physiology, pathophysiology and clinical management. Philadelphia: Saunders. 2009. pp: 561-75.

7. Marijata. Pola distribusi penderita benjolan tiroid di RSU Wonosari Gunung Kidul. BKM VII 1991; 2: 88-93.

8. Wakim AN, Polizotto SL, Buffo MJ, Marrero MA, Burholt DR. Thyroid hormones in human follicular fluid and thyroid hormone receptors in human granulosa cells. Fertil Steril 1993; 59(6):1187-90.

9. Davis LE, Leveno KJ, Cunningham FG. Hypothyroidism complicating pregnancy. Obstet. Gynecol 1988; 72(1):108-12.
10. Krassas GE, Pontikides N, Kaltsas T, Papadopoulou P, Paunkovic J, Paunkovic N, et al. Disturbances of menstruation in hypothyroidism. Clin Endocrinol (Oxf) 1999; 50(5):655-9.

11. Rohatgi T, Rohatgi N, Buckshee K. Recurring acute abdomen, ovarian cyst and hypothyroidism. JK Science 2007; 9(4):197-9.

12. Jacoeb TZ. Endokrinologi reproduksi pada wanita. In: H Wiknjosastro, AB Saifuddin, T Rachimhadhi. (Editor): Ilmu Kandungan. Jakarta: Gramedia 1997. pp: 43-96.

13. Mahendru RR, Mittal A, Gaba G. Is hypothyroidism a cause of ovarian cysts? This unusual case depicts so. Webmed Central 2011; 2(3):1-6.

14. Raber W, Nowotny P, Binstorfer EV, Vierhapper, H. Thyroxine treatment modified in infertile women according to thyroxine-releasing hormone testing: 5 year follow-up of 283 women referred after exclusion of absolute causes of infertility. Hum Reprod 2003; 18(4):707-14.

15. Jin JL, Sun J, Ge HJ, Cao YX, Wu XK, Liang FJ, et al. Association between CYP19gene SNP rs2414096 polymorphism and polycystic ovary syndrome in Chinese women. BMC Med Genet 2009; 10:16:139.

16. Leung PC, Armstrong DT. Interactions of steroids and gonadotropins in the control of steroidogenesis in the ovarian follicle. Annu Rev Physiol 1980; 42:71-82.

17. Nakamura S, Kurokawa H, Asakawa S, Shimizu N, Tanaka M. Two distinct types of theca cells in the medaka gonad: germ cell-dependent maintenance of cyp19a1-expressing theca cells. Dev Dyn 2009; 238(10): 2652-7.

18. Strauss III JF. The synthesis and metabolism of steroid hormones. In: Yen SSC, Jafee RB, editors. Reproductive endocrinology physiology, pathophysiology and clinical management. Philadelphia: Saunders 2008, pp: 79-104.

19. Bagavandoss P, England B, Asirvatham A, Bruot BC. Transient induction of polycystic ovary-like syndrome in immature hypothyroid rats. Proc Soc Exp Biol Med 1998; 219(1):77-84.

20. Ramakrishnan R. Biomath division of biomathematics/biostatistics. [cited 2011 April 11]. Available from: http://www.biomath.info 
21. Dell RB, Holleran S, Ramakrishnan R. Sample size determination. ILAR J 2002; 43(4):207-13.

22. Hapon MB, Simoncini M, Via G, Jahn GA. Effect of hypothyroidism on hormone profiles in virgin, pregnant and lactating rats, and on lactation. Reproduction 2003; 126(3):371-82.

23. Cooke PS, Kirby JD, Porcelli J. Increased testis growth and sperm production in adult rats following transient neonatal goitrogen treatment: optimization of the propylthiouracil dose and effects of methimazole. J Reprod and fertil 1993; 97(2):493-9.

24. Kanz MF, Taj Z, Moslen MT. 1,1-dichloroethelyne hepatotoxicity: hypothyroidism decreases metabolism and covalent binding but not injury in the rat. Toxicology 1991; 70(2):213-29.

25. Greenspan FS. Kelenjar tiroid. In: Greenspan FS, Baxter JD, editors. Endokrinologi dasar dan klinik. Jakarta: EGC, 2000. pp:206-89.

26. Sherwood L. Human physiology: from cells to systems. Jakarta: EGC, 2001.

27. Pranoto A. Management hyperthyroid and hypothyroid. Article presented on Surabaya Thyroid Workshop-3, August 10, Surabaya, 2008.
28. Bilesimo P, Jolivet P, Alfama G, Buisine N, Le Mevel S, Havis E, et al. Specific histone lysine 4 methylation patterns define TR-binding capacity and differentiate direct $\mathrm{T} 3$ responses. Mol Endocrinol 2011; 25(2):225-37.

29. Hatsuta M, Tamura K, Shimizu Y, Toda K, Kogo H. Effect of thyroid hormone on CYP19 expression in ovarian granulosa cells from gonadotropintreated immature rats. J Pharmacol Sci 2004; 94(4):420-5.

30. Hapon MB, Gamarra-Luques C, Jahn GA. Short term hypothyroidism affects ovarian function in the cycling rat. Reprod Biol Endocrinol 2010; $11: 8-14$.

31. Armada-Dias L, Carvalho JJ, Breitenbach MM, Franci CR, Moura EG. Is the infertility in hypothyroidism mainly due to ovarian or pituitary functional changes? Braz J Med Biol Res 2001; 34(9):1209-15.

32. Stocco C. Aromatase expression in the ovary: hormonal and molecular regulation. Steroid 2008; 73(5):473-87.

33. Goldfien A, Monroe SE. Ovarium. In: Greenspan FS, Baxter JD, Editors. Endokrinologi dasar dan klinik. Jakarta: EGC, 2000; pp:545-612. 